\title{
Factors that Influence Students' Learning: An observation on Vocational College students
}

\author{
Mohd Erfy Ismail ${ }^{1 *}$, Suhaizal Hashim², Norhasyimah Hamzah ${ }^{3}$, Noorazman Abd \\ Samad $^{4}$, Saiful Hadi Masran, Khairul Azhar Mat Daud ${ }^{6}$, Nor Fadila Mohd \\ Amin $^{7}$, Mohd Ali Samsudin ${ }^{8}$ \& Nur Zatul Shima Kamarudin ${ }^{9}$
}

${ }^{1,2,3,4,5}$ Faculty of Technical and Vocational Education, Universiti Tun Hussein Onn Malaysia, Parit Raja, Johor, 86400, MALAYSIA

${ }^{6}$ Faculty of Creative Technology and Heritage, Universiti Malaysia Kelantan, Pengkalan Chepa, Kelantan, 16100, MALAYSIA

${ }^{7}$ Faculty of Social Sciences and Humanities, Universiti Teknologi Malaysia, Skudai, Johor, 81310, MALAYSIA

${ }^{8}$ School of Educational Studies, Universiti Sains Malaysia, Gelugor, Penang, 11700, MALAYSIA

${ }^{9}$ Faculty of Educational Studies, Universiti Putra Malaysia, Serdang, Selangor, 43400, MALAYSIA

DOI: https://doi.org/10.30880/jtet.2019.11.01.012

Received $26^{\text {th }}$ August 2018; Accepted 22 October 2018; Available online $31^{\text {st }}$ March 2019

\begin{abstract}
This study examined the factors that influence students' learning for machine industry courses in Malaysian Southern Region Vocational Colleges. The factors that have been studied were the students' interest, parental involvement and teachers teaching. This study used the survey design method involving 90 randomly selected $4^{\text {th }}$ year students from three Vocational Colleges as respondents. Primary data were obtained using questionnaires (Cronbach Alpa $=.85$ ) and secondary data were based on students' academic performance test result. The data were analysed with the aid of the Statistical Package for Social Sciences (SPSS) to get the frequency, percentage, mean and standard deviation. The results showed that there was a medium level of influence between students' achievement and students' interest, parental involvement and teachers teaching. For student interest factor, students who have good achievement in some subjects were those who have an interest in the subject. In addition, the involvement of parents helping in students' assignment at home will help them to improve their achievement in school. Next, in the process of teaching, the teacher must inflict the interest of student learning, guiding them in an effective learning way, provide teaching materials and improve their mastery skills. Some suggestions to overcome the challenges identified in this study were also presented at the end of the study.
\end{abstract}

Keywords: Achievement, parental involvement, students' interest, teacher's teaching style

\section{Introduction}

The technical and vocational education and training (TVET) sector of the Malaysian education system is undergoing transformations to better meet the new challenges posed by the ongoing industrial revolution. The ongoing industrial revolution raises new industry needs and demands which are to be met by TVET graduates who must be equipped with the appropriate skills, attitude and knowledge. The necessary academic achievements are thus determined by these industry needs and demands. 
Academic achievements are however influenced by many internal as well as external factors. Some of the factors are, gender, age, prior knowledge, traveling time, family income, combined study, attendances and internet usage for study (Akessa and Dhufera, 2015). Furthermore, Van Rooij, Jansen, and Van de Grift (2017) found that school achievement itself is one of the key factors that can determine academic success. Due to the many influencing factors, the need for studying TVET provisions have been the target of academic and industrial discussions nationwide, which is important in determining the success of the TVET transformation plans. The multitude of factors involved raise the need to study the main factors that influence the excellence level of TVET students in order to make positive impact to the TVET system to meet the current demand of the ongoing industrial revolution. Currently, there are limited studies that look into the relationship between student's interest (an important internal factor), parental involvement and teachers teaching (external factors) in TVET and students' success in learning.

Vocational Colleges are institutions that have been established to meet the agenda of TVET transformation plan in Malaysia. Being new, teachers and students have greater challenges in executing the various plans effectively. Any effort to understand how success among TVET Vocational college students can be realised is much needed. Thus, the aim of this study was to investigate the main three factors that contribute to students' success focussing on students' interest, parental involvement and teachers teaching.

\subsection{Student's Interest}

Students' interest in their learning are being challenged from the various competitors that compete for students' attention, which can influence their focus on their studies. These $n$ opportunities which arises from many factors can lead to the decline of interest on their studies which ultimately affect their academic achievement. Among the multitude of factors, Wilder (2014) proposed that personal interest, involvement of parents and teachers are the main factors that can affect a student's achievement.

Thus, is is expected that students' interest in contributing to their achievements is highly related to their academic achievement. This argument is supported by Lee, Lee, and Bong (2014), which shows that the interest in studying a subject is positively associated with student achievement. According to Muller (2018); Wilder (2014) there is a difference in students' academic achievement according to interest level. This is supported by other scholars such as, Park, Holloway, Arendtsz, Bempechat, and Li (2012) who found that students who have a high interest will be more successful academically, while students who are less interested tend to be low-performers academically. This support the conclusion that a lack of interest would make a person gets low academic achievement.

Wan, Wong, and Kong (2014) also argue that the existing interest in the students will catalyse and lead to a better job. It means that interest is a matter that is important for a student to be able to determine their tendency to any direction. To arouse the interest, parents should know the interests of their schooling children or teenagers. Parental involvement is commonly referred to as the participation of parents in the education of their children in order to promote their social and academic success (Castro et al., 2015; Niehaus \& Adelson, 2014; Núñez et al., 2017). With this regard, the involvement of parents is very important to encourage student's learning. For teachers, they are parents for the student while in school. Rules of engagement for the quality teacher can influence the development and achievement in education. Adnot, Dee, Katz, and Wyckoff (2017) showed that teachers are the one who aspects that need to be emphasized to influence student's achievement.

\subsection{Parental Roles}

Parents also play an important role in encouraging the students to obtain better results with their guidance. According to Rodriguez, Blatz, and Elbaum (2014) parents are less involved in their children's education in high school. This shows that parents are less involved with school activities and many parents still lack of sufficient information about parenting the children (Seymour, 2017; Solomon, Niec, \& Schoonover, 2017). The involvement of parents in school is decreasing in activities and programs that have impact on students' achievement (Wang \& Sheikh Khalil, 2014). Curry, Jean-Marie, and Adams (2016) also state that parental relationship with the school is still tenuous. Parents who involved with the school-related activities and fundraising cooperative were involved in activities related to their children's (Park, Stone, \& Holloway, 2017). According to Lendrum, Barlow, and Humphrey (2015); Pemberton and Miller (2015) the lack of parental guidance regarding learn at home means most of the parents in developed countries provide less guidance in completing the task and also do not send their children to tuition for homework revision.

\subsection{Teacher Teaching Style}

In the context of teacher teaching style in classroom, it plays an important role for teachers to attract a student to learn. According to $\mathrm{Ng}$, Nicholas, and Williams (2010), that is less evident in the instructional process can affect the student's understanding. Here we can see that when teachers instructional not clear will lead to a lack of understanding of students. According to Ismail, Nopiah, Rasul and Leong (2017) there were less-skilled teachers who will implement the means of engagement in practical work without making a demonstration. The shortage of competent teachers to teach skills will 
bring an impact on student achievement, lack of skill knowledge will occur to them and this would be detrimental to the students under their guidance (Hashim, 2015 \& Mohd Hashim and Abubakar, 2017). Junejo, Sarwar, and Ahmed (2018) stated that the weakness of teachers is to communicate effectively that will lead learning objectives and teaching unsuccessful.

\section{Methodology}

The study used a quantitative survey research design. A questionnaire survey design was aimed at to determine the factors that influence students' learning. Questionnaires were used to collect data as it provides an opportunity to gather data from a large group of respondents, and tend to have a high reliability and low cost when properly designed and administered. There are three main constructs that were measured, student's interest, parental roles, and teachers' teaching style. For each construct, five verified items were used. The population of this research consisted of different vocational colleges, VC. A number of $\mathrm{VC}=\left\{\mathrm{VC} i \mid i=1,2,3 \ldots \mathrm{N}_{\mathrm{vc}}\right\}$ which was purposely selected for this study. In this study, a total of three different vocational colleges were selected and the target population were students who were enrolled in the Machinery Industry Courses (Code MC). Sample selection is based on the random sampling method with population and sample size shown in Table 1.

Table 1 - Population and sample

\begin{tabular}{llcc}
\hline No. & Vocational College $(\mathbf{V C})$ & Population & Selected Sample \\
\hline 1 & Vocational College A $\left(\mathrm{VC}_{1}\right)$ & 90 & 35 \\
2 & Vocational College B $\left(\mathrm{VC}_{2}\right)$ & 81 & 35 \\
3 & Vocational College C $\left(\mathrm{VC}_{3}\right)$ & 90 & 35 \\
\hline & Total & & 105 \\
\hline
\end{tabular}

A pilot study was conducted to test whether the questionnaire items could provide reliable data for the construct after an expert in content validates all items of questionnaires. The result shows that the value of Cronbach alpha coefficient from the pilot study for student's interest, parental involvement and teachers' teaching style are $.83, .82$ and 0.89 respectively with an overall reliability coefficient of .85 . The high values indicate a reliable instrument and the data gathered using the instrument were analysed descriptively using SPSS (Statistical Package for the Social Sciences). The data analysis results are discussed in the next section.

\section{Results}

Descriptive data analysis was conducted by calculating the mean score and standard deviation on the questionnaire items with the aid of SPSS. The mean values obtained were then classified into three categories, low, medium and high indicating the level of interest of students, parental involvement and teachers teaching for the course of the machining industry.

Table 2 shows the finding of the mean values and the standard deviations obtained from three different colleges. For each item was analysed to determine if the levels of this construct were associated with students' achievement (highest, medium or low). Table 2 shows that $\mathrm{VC}_{2}$ obtained the highest average mean for overall items.

Table 2 - Mean value and standard deviation for student's interest towards student's learning

\begin{tabular}{|c|c|c|c|c|c|c|c|}
\hline \multirow[t]{3}{*}{ No. } & \multirow[t]{3}{*}{ ITEMS } & \multicolumn{6}{|c|}{ Vocational College } \\
\hline & & \multicolumn{2}{|c|}{$\mathbf{V C}_{1}$} & \multicolumn{2}{|c|}{$\mathbf{V C}_{2}$} & \multicolumn{2}{|c|}{$\mathrm{VC}_{3}$} \\
\hline & & Mean & SD & Mean & SD & Mean & SD \\
\hline A1 & Interested in the machining industry course & 3.60 & 0.50 & 3.70 & 0.48 & 3.50 & 0.51 \\
\hline A2 & $\begin{array}{l}\text { Participate in hands-on activities machining } \\
\text { industry. }\end{array}$ & 3.60 & 0.50 & 3.57 & 0.54 & 3.63 & 0.50 \\
\hline A3 & Love to learn machining industry course. & 3.60 & 0.50 & 3.53 & 0.51 & 3.40 & 0.50 \\
\hline A4 & Pay attention during learning in class. & 3.10 & 0.51 & 3.53 & 0.51 & 3.40 & 0.50 \\
\hline A5 & Finished the assignment early before the due date. & 3.40 & 0.61 & 3.47 & 0.51 & 3.67 & 0.48 \\
\hline & Total (Average Mean) & 3.46 & - & 3.56 & - & 3.52 & - \\
\hline
\end{tabular}

Then, Table 3 shows the influence of the parental involvement toward student's achievement. $\mathrm{VC}_{2}$ presents the higher mean values on the involvement of parents in discussing assignments, checking and having a good relationship between parents and students. 
Table 3 - Mean value and standard deviation for parental involvement towards student's learning Vocational College

\begin{tabular}{llcccccc}
\multirow{2}{*}{ No. } & \multicolumn{2}{c}{ ITEMS } & \multicolumn{2}{c}{$\mathbf{V C}_{\mathbf{1}}$} & \multicolumn{2}{c}{$\mathbf{V C}_{\mathbf{2}}$} & \multicolumn{2}{c}{$\mathbf{V C}_{\mathbf{3}}$} \\
\cline { 3 - 7 } & & Mean & $\mathbf{S D}$ & $\mathbf{M e a n}$ & $\mathbf{S D}$ & $\mathbf{M e a n}$ & $\mathbf{S D}$ \\
\hline B1 & I am talking about assignments with my parents. & 3.30 & 0.48 & $\mathbf{3 . 5 3}$ & 0.51 & 2.87 & 1.04 \\
B2 & Parents always check the assignments made by me. & 2.90 & 0.51 & $\mathbf{3 . 4 3}$ & 0.50 & 2.83 & 1.12 \\
B3 & My parents cared about each exam marks. & $\mathbf{3 . 5 0}$ & 0.57 & 3.43 & 0.50 & 2.60 & 1.16 \\
B4 & My parents get involved with activities in college. & $\mathbf{3 . 1 0}$ & 0.69 & 2.47 & 1.10 & 2.23 & 1.04 \\
B5 & $\begin{array}{l}\text { My parents have a good relationship with the teachers } \\
\text { in the school. }\end{array}$ & 3.00 & 0.69 & $\mathbf{3 . 5 7}$ & 0.51 & 3.00 & 1.14 \\
& Total (Average Mean) & 3.16 & - & $\mathbf{3 . 2 9}$ & - & 2.71 & - \\
\hline
\end{tabular}

Lastly, Table 4 shows the finding on the influence of teachers' instructional factors toward the student's learning. $\mathrm{VC}_{3}$ obtained the higher mean value on the interaction among students and teachers, delivery process, and instructional tools/materials.

Table 4 - Mean value and standard deviation for teacher teaching style towards student's learning

\begin{tabular}{|c|c|c|c|c|c|c|c|}
\hline \multirow{3}{*}{ No. } & \multirow{3}{*}{ ITEMS } & \multicolumn{6}{|c|}{ Vocational College } \\
\hline & & \multicolumn{2}{|c|}{$\mathrm{VC}_{1}$} & \multicolumn{2}{|c|}{$\mathrm{VC}_{2}$} & \multicolumn{2}{|c|}{$\mathbf{V C}_{3}$} \\
\hline & & Mean & SD & Mean & SD & Mean & SD \\
\hline $\mathrm{C} 1$ & I like the teaching of teachers machining industry. & 3.37 & 0.49 & 3.71 & 0.45 & 3.57 & 0.50 \\
\hline $\mathrm{C} 2$ & $\begin{array}{l}\text { My machining subject teachers have attracted students } \\
\text { effectively. }\end{array}$ & 3.43 & 0.50 & 3.60 & 0.49 & 3.47 & 0.51 \\
\hline $\mathrm{C} 3$ & $\begin{array}{l}\text { While teaching, my teacher gives a fair attention to all } \\
\text { students. }\end{array}$ & 3.30 & 0.65 & 3.53 & 0.51 & 3.63 & 0.49 \\
\hline $\mathrm{C} 4$ & $\begin{array}{l}\text { Teachers have provided many opportunities for students to } \\
\text { ask questions. }\end{array}$ & 3.47 & 0.51 & 3.37 & 0.49 & 3.50 & 0.51 \\
\hline C5 & Teachers use many teaching aids. & 3.17 & 0.75 & 3.50 & 0.51 & 3.57 & 0.50 \\
\hline & Total & 3.35 & - & 3.54 & - & 3.55 & - \\
\hline
\end{tabular}

\section{Discussion}

Analyses results indicate that students' interest in pursuing a course, as a strong interest lead the student to excel and gain excellent achievement. This finding was supported by the previous studies such as those by Boonk (2018), Ismail (2017), Joong (2017), Yulianti (2018)who found that students' achievement has a relationship with interest, teacher's instructional practices and parental involvement. Similar trend differences was observed in mean and standard deviation for the three VCs groups. These varying results could be attributed to students' background factors such as family income, as well as facility and environment for learning (Hashim, Mohamad \& Muda, 2018).

The findings also show that students' interest in the course (whether taking a course was based on self-selection or was forced selection) is reflected in the learning process of the student. This statement is in line with the findings by Hashim (2012) and Wilder (2014) which states that the interest which arises in a student will affect the learning process. In addition, engagements in teaching and learning is one of the things necessary to ensure that a student either interest or not. This statement is in line with previous studies which is student's interest in learning; will encourage students to think critically (Cheng, 2014; Stupple, 2017) . Besides, students will be active in the classroom will be willing to work in groups and will improve the skills of interacting and communicating (Denker, 2018; Heflin, 2017).

The involvement of parents in terms of encouraging and helping students to do homework is shown to be something that can give a good impact on student achievement. This is in line with the study from Wang and Sheikh Khalil (2014) which states that the involvement of parents in student's homework that given by the teacher at school will make students improve their academic achievement in school. Parental monitoring of assignments given by the teacher can also help students better understand more clearly and attained good achievements (Boonk, 2018). The finding is consistent with the fact from Wang and Sheikh Khalil (2014) that the presence of parental involvement in children's education, especially monitoring at home and in school, the family attempted to modify the child's behaviour to achieve success. Parental involvement from the point of care in respect of child volatility achievement by asking questions about the scores in each 
exam they earn. This statement is consistent whereby parents need to interact with the students until they reach the desired success (Doctoroff, 2017).

Thus, parents must establish ways with teachers and involve with VC activities through participation in parentteacher association (PTA) regarding their children academic performance in school. The findings of parental involvement did not end at home, but parents should cooperate with teachers so that both can understand and achieve success or agreement in an effort to improve student's achievement (Muller, 2018; Wilder, 2014). Teachers need to know how to diversify the teacher teaching style in the classroom. Because teachers were creative in teaching in the classroom can attract students to concentrate on the content of the subject to be conveyed by a teacher. Thus, it can provide information that is understandable to students (Adnot et al., 2017). The effective instructional requires teachers who are good and be able to motivate students in learning (Csikszentmihalyi, 2014; Entwistle, 2014). Besides, teachers must make the instruction clearer for students to focus on the content easily, understandable and not misleading. In the process of instructional, the teacher must arouse the interest of student learning, guiding them in the way of effective learning, clarify doubts, help them in solving problems, providing instructional materials, and improving their skills mastery. Teachers will make students more comfortable to ask and answer questions (Gray, Chang, \& Anderman, 2015).

From the analysis of the study, it can be seen that in the use of teaching aids, there is an initiative to diversify teachers' instruction in the classroom for students to attract more focus on teachers teaching. The attractiveness of teaching depends on the skills and methods of teachers instructional. In addition, the relationship between teachers and students must be in good condition for the implementation of a good relationship this will make students more comfortable and confident to ask questions that are not understood. The teacher teaching style in the classroom can have an impact on student learning and academic achievement (Broadbent \& Poon, 2015; Han, Capraro, \& Capraro, 2015; Kikas, Silinskas, Jõgi, \& Soodla, 2016).

\section{Conclusion}

In conclusion, this study shows that internal and external factors play important roles in ensuring students' academic learning. Firstly, student's interest is one of the main factors that effect on their achievements. Secondly, parent's involvement is an essential external factor to be taken into account because it can be linked with the behaviour improvement, positive attitudes among the students. Thirdly, an instructor's teaching style and practices such as being approachable, prepared, and genuinely cared about their students' learning can lead to greater students' interest and efforts and ultimately to students' success. Thus, personal factor such interest and external factors such as parental involvement and teachers' classroom teaching practices are determinant of students' potential success.

\section{Acknowledgement}

This research was fully funded by the PPG Grant Scheme Vot. No. 027 from the Research Management Center (RMC), Universiti Tun Hussein Onn Malaysia. We thank our colleagues from the Universiti Malaysia Kelantan, Universiti Teknologi Malaysia, Universiti Sains Malaysia and Universiti Putra Malaysia who provided insights and expertise that greatly assisted the research.

\section{References}

Adnot, M. D, Thomas, K. V, \& Wyckoff, J. (2017).Teacher turnover, teacher quality, and student achievement in DCPS. Educational Evaluation and Policy Analysis, 39(1), 54-76.

Akessa, G. M, \& Dhufera, A.G. (2015). Factors That Influences Students Academic Performance: A Case of Rift Valley University, Jimma, Ethiopia. Journal of Education and Practice, 6(22), 55-63.

Boonk, L., Gijselaers, H. J., Ritzen, H., \& Brand-Gruwel, S. (2018). A review of the relationship between parental involvement indicators and academic achievement. Educational Research Review, 24, 10-30.

Broadbent, J. \& Poon, W. L. (2015). Self-regulated learning strategies \& academic achievement in online higher education learning environments: A systematic review. The Internet and Higher Education, 27, 1-13.

Castro, M., Expósito-Casas, Eva., López-Martín, E., Lizasoain, L., Navarro-Asencio, E., \& Gaviria, J.L (2015). Parental involvement on student academic achievement: A meta-analysis. Educational research review, 14, 33-46.

Cheng, G. (2014). Exploring students' learning styles in relation to their acceptance and attitudes towards using Second Life in education: A case study in Hong Kong. Computers and Education, (70), 105-115.

Csikszentmihalyi, M. (2014). Intrinsic motivation and effective teaching Applications of flow in human development and education (pp. 173-187): Springer.

Curry, K.A., Jean, M.G., \& Adams, C. M. (2016). Social networks and parent motivational beliefs: Evidence from an urban school district. Educational Administration Quarterly, 52(5), 841-877. 
Denker, K. J., Manning, J., Heuett, K. B., \& Summers, M. E. (2018). Twitter in the classroom: Modeling online communication attitudes and student motivations to connect. Computers in Human Behavior, 79(1-8).

Doctoroff, G. L., \& Arnold, D. H. (2017). Doing homework together: The relation between parenting strategies, child engagement, and achievement. Journal of Applied Developmental Psychology, 48, 103-113.

Entwistle, N. (2014). Motivation and approaches to learning: Motivating and conceptions of teaching Motivating students (pp. 25-34): Routledge.

Gray, D.L., Chang, Y., \& Anderman, E.M. (2015). Conditional effects of mastery goal structure on changes in students' motivational beliefs: Need for cognition matters. Learning and Individual Differences, 40, 9-21.

Han, S., Capraro, R., \& Capraro, M.M.(2015). How science, technology, engineering, and mathematics (STEM) projectbased learning (PBL) affects high, middle, and low achievers differently: The impact of student factors on achievement. International Journal of Science and Mathematics Education, 13(5), 1089-1113.

Hashim, M. H. M. (2012). Group blogs as toolkits to support learning environments in statistics subject: A qualitative case study. International Education Studies, 5(3), 199.

Hashim, M. H. M. (2015). Using technology and instructional e-material among technical teacher and student into teaching and learning: A qualitative case study. International Education Studies, 8(3), 175.

Mohd Hashim, M. H., \& Abubakar, B. (2017). The Availability of Electronic Courses Using ICT Infrastructure in Teaching and Learning among Teachers in Nigeria's TVET Institutions. Pertanika Journal of Social Sciences \& Humanities.

Hashim, S., Mohamad, M. M., \& Muda, W. H. N. W. (2018). Knowledge Construction Models: A view of Various Models for an Impeccable Learning Environment. In MATEC Web of Conferences (Vol. 150, p. 05013). EDP Sciences.

Heflin, H., Shewmaker, J., \& Nguyen, J. (2017). Impact of mobile technology on student attitudes, engagement, and learning. Computers and Education, 107, 91-99.

Ismail, K., Nopiah, Z. M., Rasul, M. S., \& Leong, P. C. (2017). Malaysian Teachers' Competency in Technical Vocational Education and Training: A review. Proceeding of Regionalization and Harmonization in TVET-Abdullah et al.(Eds). London: Taylor \& Francis Group.

Ismail, M.E., Samsudin, M.A., Ismail, A., \& Halim, L. (2017). Factors Related To Science Achievement In TIMMS Malaysia: A Confirmatory Factors Analysis. Man in India, 9(2), 873-888.

Joong, P., Xiong, Y., Li, L., \& Pan, C. J. (2017). Investigation into the Perceptions of Students, Parents, and Teachers in China's Education Reform in Grades 7 and 8. International Electronic Journal of Elementary Education, 1(3), 141154.

Junejo, M.I., Sarwar, S. , \& Ahmed, R.R. (2018). Impact of In-Service Training on Performance of Teachers A Case of STEVTA Karachi Region. International Journal of Experiential Learning \& Case Studies, 2(2), 50-60.

Kikas, E., Silinskas, G., Jõgi, A., \& Soodla, P. (2016). Effects of teacher's individualized support on children's reading skills and interest in classrooms with different teaching styles. Learning and Individual Differences, 49, 270-277.

Lee, W., Lee, M.J, \& Bong, M. (2014). Testing interest and self-efficacy as predictors of academic self-regulation and achievement. Contemporary educational psychology, 39(2), 86-99.

Lendrum, A., Barlow, A., \& Humphrey, N. (2015). Developing positive school-home relationships through structured conversations with parents of learners with special educational needs and disabilities (SEND). Journal of Research in Special Educational Needs, 15(2), 87-96.

Muller, C. (2018). Parent involvement and academic achievement: An analysis of family resources available to the child Parents, their children, and schools (pp. 77-114): Rutledge.

Ng, W., Nicholas, H, \& Williams, A. (2010). School experience influences on pre-service teachers' evolving beliefs about effective teaching. Teaching and Teacher Education, 26(2), 278-289.

Niehaus, K., \& Adelson, J.L. (2014). School support, parental involvement, and academic and social-emotional outcomes for English language learners. American Educational Research Journal, 51(4), 810-844.

Núñez, J. C., Epstein, J.L., Suárez, N., Rosário, P., Vallejo, G., \& Valle, A. (2017). How do student prior achievement and homework behaviors relate to perceived parental involvement in homework? Frontiers in psychology, 8, 1217. 
Park, S., Holloway, S. D., Arendtsz, A., Bempechat, J., \& Li, J. (2012). What makes students engaged in learning? A time-use study of within-and between-individual predictors of emotional engagement in low-performing high schools. Journal of youth and adolescence, 41(3), 390-401.

Park, S., Stone, S.I., \& Holloway, S.D. (2017). School-based parental involvement as a predictor of achievement and school learning environment: An elementary school-level analysis. Children and Youth Services Review, 82, $195-206$.

Pemberton, K.D., \& Miller, S. (2015). Building home-school relationships to enhance reading achievement for students from families with limited financial resources. Education and Urban Society, 47(7), 743-765.

Rodriguez, R. J, Blatz, E.T, \& Elbaum, B. (2014). Parents' views of schools' involvement efforts. Exceptional Children, 81(1), 79-95.

Seymour, C. (2017). Introduction: Children with Parents in Prison: Child Welfare Policy, Program, and Practice Issues Children with parents in prison (pp. 1-26): Routledge.

Solomon, D. T, Niec, L. N, \& Schoonover, C.E. (2017). The impact of foster parent training on parenting skills and child disruptive behavior: a meta-analysis. Child maltreatment, 22(1), 3-13.

Stupple, E. J., Maratos, F. A., Elander, J., Hunt, T. E., Cheung, K. Y., \& Aubeeluck, A. V. (2017). Development of the Critical Thinking Toolkit (CriTT): A measure of student attitudes and beliefs about critical thinking. Thinking Skills and Creativity, 23, 91-100.

Van Rooij, E. C.M., Jansen, E.P.W.A., \& Grift, W.J.C.M. (2017). Secondary school students' engagement profiles and their relationship with academic adjustment and achievement in university. Learning and Individual Differences, 54, 919.

Wan, Y.K. P., Wong, I. A., \& Kong, W.H. (2014). Student career prospect and industry commitment: The roles of industry attitude, perceived social status, and salary expectations. Tourism Management, 40, 1-14.

Wang, M.T., \& Sheikh, K.S. (2014). Does parental involvement matter for student achievement and mental health in high school? Child development, 85(2), 610-625.

Wilder, S. (2014). Effects of parental involvement on academic achievement: a meta-synthesis. Educational Review, $66(3), 377-397$.

Yulianti, K., Denessen, E., \& Droop, M. (2018). The effects of parental involvement on children's education: a study in elementary schools in Indonesia. International Journal About Parents in Education, 10, 14-32. 